Jurnal Ilmu Dan Teknologi Kesehatan

Vol 8, No 2, March 2021,

ISSN: 2338-9095 (Print)

ISSN: 2338-9109 (online)

\title{
Survival Rate Prediction of Head Injury Patients with Peripheral Oxygen Saturation
}

\author{
Nurma Afiani $^{1}$, Abdul Qodir ${ }^{2}$, Wiwit Widyawati $^{3}$, Intan Purnama ${ }^{4}$ \\ ${ }^{1,2,4}$ STIKES Widyagama Husada Malang, Indonesia \\ ${ }^{3}$ RSUD Bangil Kabupaten Pasuruan, Indonesia \\ Email: nurmaafiani@widyagamahusada.ac.id
}

\section{Article history}

Posted, Jan 11th, 2021

Reviewed, Jan 15th, 2021

Received, Feb 23rd, 2021

\begin{abstract}
Good management of head injuries can improve patient survival. Examination of peripheral oxygen saturation ( $\mathrm{SpO} 2$ ) is a procedure performed at the primary survey. This study aims to predict the survival rate of head injury patients with the SpO2 value. The method used was a prospective study with a cohort design. Samples were head injury patients who came to the ER without comorbidities. The instruments used were the Revised Trauma Score (RTS) and Oximetry. Patients who arrived at the ER were measured for their SpO2 levels, treated according to SOP, and 6 hours later, the survival rates were assessed. The sampling technique used was purposive sampling. The statistical test used is Somers'd Correlation Test. The sample consisted of 46 head injury patients with SpO2 in a good category of 30 $(65.2 \%)$ and good survival of $32(69.6 \%)$. SpO2 had a strong correlation with survival ( $p=$ $0.00 ; r=0.846 ; R R=8.16)$. Patients with good $\mathrm{SpO} 2$ were 8.16 times more survive than others. Low SpO2 can be used as an early indicator of tissue hypoxia and related to mortality. The ER nurse should be concerned about the patient's oxygen saturation and ensure that the SpO2 level is in the 95\% - 100\% range.
\end{abstract}

Keywords: head injury; peripheral oxygen saturation; prognosis; $\mathrm{SpO}_{2}$; survival

\begin{abstract}
ABSTRAK
Tatalaksana cedera kepala secara tepat dan cepat dapat meningkatkan survival pasien. Pemeriksaan saturasi oksigen perifer $\left(\mathrm{SpO}_{2}\right)$ merupakan prosedur yang dilakukan pada tahap primary survey. Penelitian ini bertujuan untuk memprediksi tingkat survival pasien cedera kepala dengan nilai $\mathrm{SpO}_{2}$. Metode yang digunakan adalah studi prospektif dengan rancangan kohort. Sampel merupakan pasien cedera kepala yang datang ke IGD tanpa cedera pada organ lain. Instrumen yang digunakan adalah Revised Trauma Score (RTS) dan Oksimetri. Pasien yang tiba di IGD diukur kadar $\mathrm{SpO}_{2}$ nya, dilakukan penanganan sesuai SOP dan 6 jam kemudian dinilai tingkat survivalnya. Teknik sampling yang digunakan adalah purposive sampling. Uji statistik yang digunakan adalah Uji Korelasi Somers'd. Sampel terdiri atas 46 pasien cedera kepala dengan $\mathrm{SpO}_{2}$ dalam kategori baik sejumlah $30(65,2 \%)$ dan survival
\end{abstract}


baik sejumlah $32(69,6 \%) . \mathrm{SpO}_{2}$ memiliki korelasi yang kuat terhadap survival pasien $(\mathrm{p}=0,00 ; \mathrm{r}=0,846 ; \mathrm{RR}=8,16)$. Pasien dengan $\mathrm{SpO}_{2}$ baik 8,16 kali lebih survive dibandingkan pasien dengan $\mathrm{SpO}_{2}$ buruk. Saturasi oksigen yang rendah dapat digunakan sebagai indikator awal terjadinya kondisi hipoksia jaringan dan berkaitan erat dengan tingkat mortalitas pasien. Perawat IGD diharapkan melakukan observasi ketat terhadap saturasi oksigen pasien dan memastikan kadar $\mathrm{SpO}_{2}$ pada rentang 95\%-100\%.

Kata Kunci: cedera kepala; prognosis; saturasi oksigen perifer; $\mathrm{SpO}_{2}$; survival

\section{INTRODUCTION}

Head injury is the leading cause of disability and mortality worldwide, with traffic accidents was the biggest problem (Papadimitriou-Olivgeris et al., 2020). This condition generally occurs in motorbike drivers without a helmet or wearing a not standard helmet (Marya et $a l .$, 2017). Head injury is a very lifethreatening condition associated with the initial level of brain damage and secondary pathology (Papadimitriou-Olivgeris et al., 2020). The mortality rate in head injury patients is classified into three parts, consisting of immediate deaths (in the first 1 hour), early deaths (in the first 24 hours), late deaths (after the first 24 hours) (Papadimitriou-Olivgeris et al., 2020). Head injury ranks first in Indonesia, where victims of traffic accidents are $33.2 \%$. Based on the results of basic health research (RISKESDAS) in 2013, the total amount of data analyzed was 1,027,758 people for all ages. The respondents who had experienced injuries were 84,774 people, and 942,984 people were not injured. National injury prevalence is
$8.2 \%$, and head injury prevalence in North Sulawesi is $8.3 \%$. The highest prevalence of injury based on the characteristics of the respondent was in the 15-24 year age group (11.7\%) and men (10.1\%) (Riskesdas, 2018).

The management of head injuries should start from the scene of the incident, during transportation, in the Emergency Department, to definitive therapy. Right, and fast treatment will affect the patient's survival rate (Dixon et al., 2020). The ability to predict head injury patients' mortality at an early stage can provide good information for the treatment in later stages (HoonLee et al., 2018). Head injury management's main goals are to optimize recovery from primary head injuries and prevent secondary head injuries (Dixon et $a l ., 2020)$. In the primary survey treatment, the prioritized matters include Airway, Breathing, Circulation, Disability, and Exposure, followed by resuscitation (Dixon et al., 2020). Patients with head injuries often experience cardiopulmonary 
disorders. Therefore the sequence of actions is to overcome airway, respiratory and circulation disorders to prevent secondary brain injury and maintain brain homeostasis. Maintaining to remain hemostatic, one of which is by monitoring oxygen saturation, namely the presentation of hemoglobin that binds to oxygen in the arteries, normal oxygen saturation is between 95 - 100\% (Sumarno, 2016).

Failure to supply oxygen within 5 minutes can result in permanent brain damage (Ostrowski, Pucko, and Matyja, 2020). An easy way to detect hypoxemia is by monitoring oxygen saturation levels to measure how much of the percentage of O2 hemoglobin can carry (Wijaya, 2013). Monitoring oxygen saturation levels can be done by monitoring using a peripheral oxygen saturation oximetry ( $\mathrm{SpO} 2)$. Monitoring the correct and appropriate peripheral oxygen saturation levels when acting, especially in head injury patients, can reduce poor clinical outcomes (Irmawan, 2017).

Various studies have been conducted to show the relationship between these oxygen saturation values and mixed results. Newer prognostic parameters and supporting tests have helped determine the potential for functional healing. Head injury severity, peripheral oxygen saturation, and temperature are significant predictors of patient mortality and morbidity (Filipescu et al., 2020). In this case, the researchers wanted to prove scientifically that the peripheral oxygen saturation value is an essential indicator for assessing patients' prognosis with a head injury. This study analyzes the correlation between head injury patients' survival rate with peripheral oxygen saturation values. The assessment of head injury patients' survival rate in this study was carried out 6 hours after the patient entered the ER (Emergency Room). This timing is considered superior to previous studies where (Irawan, 2010) measured the survival rate 24 hours after the patient entered the emergency room. The earlier the nurse can predict the patient's survival rate, the more optimal the patient's treatment process will be. The survival rate in head injury patients in this study was measured using the RTS (Revised Trauma Score) instrument. This instrument is better than similar instruments such as the GCS (Glasgow Coma Scale), the Barthel Index (BI), and the Functional Independence Measure (FIM). RTS can assess the human physiological system as a whole and result from a refinement of 
the GCS instrument to assess head trauma patients' initial condition. This instrument assesses physiological conditions with high reliability between raters and demonstrated accuracy in predicting mortality. RTS assessments are performed immediately after the patient is traumatized, generally while in the ER. RTS has been validated as a research method to differentiate between patients with good and bad prognoses. RTS has predictive ability substantially with an alpha value of 0.84 . If the alpha value is 0.84 , the result of the level of reliability is very reliable.

\section{METHOD}

The method used was a prospective study with a cohort design. Samples were head injury patients who came to the ER without serious injury to other organs, not referral patients, aged less than 45 . The research was conducted at the ER of Bangil Hospital, Pasuruan, East Java, Indonesia for three months from February to April 2020. The sampling technique used was purposive sampling. The following scheme 1 describes the data collection procedure in the study.

Schema. 1. Data Collection Procedure for Head Injury Patient Research (February-April 2020)

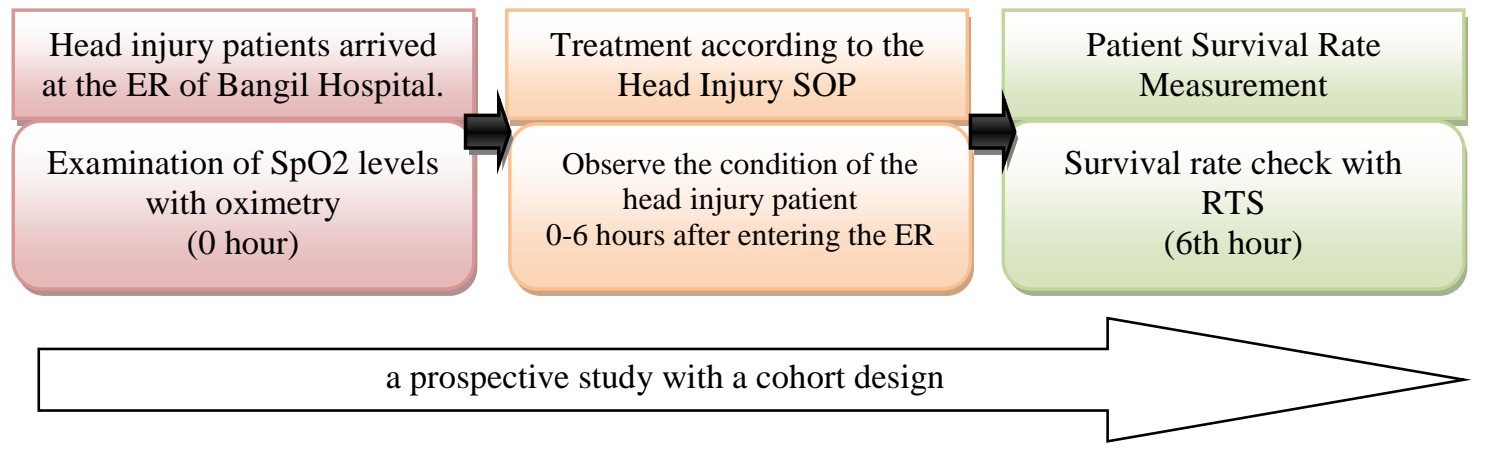

Patients who arrived at the ER were subjected to informed consent from both the family and the patient. The sample that met the inclusion criteria was 46 head injury patients. After triage and receiving initial treatment by the ER team, peripheral oxygen saturation was examined. Researchers conducted observations of patients, and 6 hours later, an assessment of the patient's survival rate was carried out. The instruments used were oximetry and the Revised Trauma Score (RTS). Oximetry connected to the monitor screen is used to assess peripheral oxygen saturation. RTS is better than GCS in assessing head injury patients' prognosis (HoonLee et al., 2018). RTS was used to assess patients' survival rate treated for 6 
hours in the ER. The statistical test used is the Somers'd Correlation Test. Also, researchers calculated the Relative Risk (RR) on the research variables. This research has been declared worthy of ethics by the Eligible Team for Health Ethics at Bangil Hospital, Pasuruan Regency, with a letter-number 445.1/1432/424.202/2020.

\section{RESULTS AND DISCUSSION}

In the research process, data was collected on the respondents' characteristics such as age, gender, and work type. Factors related to head injury cases in patients were also identified, including the degree of head injury, the type of transportation used to deliver the patient to the emergency room, peripheral oxygen saturation of the patient, and the patient's clinical outcome. Table 1 presents the characteristics of the respondents in this study. The data presented in the table results from an assessment of the respondent's characteristics using several instruments. The instrument used to assess the degree of head injury was the Glasgow Coma Scale (GCS). Peripheral Oxygen Saturation $(\mathrm{SpO} 2)$ data in patients were obtained from oximetry placed on the patient's finger and linked to a screen (monitor). In contrast, the patient's survival rate was measured by the Revised Trauma Score (RTS).

Table 1. Characteristics of Respondents in Head Injury Patients $(n=46)$

\begin{tabular}{llrr}
\hline Characteristics of Respondents & $(\mathbf{n})$ & $\mathbf{( \% )}$ \\
\hline Age (Year) & $12-16$ & 13 & 28,3 \\
& $17-25$ & 6 & 13,0 \\
& $26-35$ & 12 & 26,1 \\
& $36-45$ & 15 & 32,6 \\
\hline Sex & Man & 24 & 52,2 \\
& Woman & 22 & 47,8 \\
\hline Work & Housewife & 10 & 21,7 \\
& Entrepreneur & 16 & 34,8 \\
& Student & 15 & 32,6 \\
& Civil Servant & 2 & 4,3 \\
& Farmer & 3 & 6,5 \\
\hline Transportation & Ambulance & 5 & 10,9 \\
& Public & 19 & 41,3 \\
& Transportation & & \\
& Private & 22 & 47,8 \\
& Transportation & & \\
\hline
\end{tabular}


The majority of respondents in this study belonged the aged 36 to 45 years. Head injury is the leading cause of death at young and productive ages (R.Gallahera $e t$ al., 2020). Many kinds of literature state that children with head injuries have a better prognosis than adults. The research report states that a significant increase in the percentage of bad outcomes occurs in patients over 56 years of age who are accompanied by systemic disease patients (G. Lakshmi Prasad, N. Anmol, 2018). The high incidence of head trauma in the age range 12-45 years is due to being busy or the high mobility level. Age 17-45 is the productive age, where they have a lot of activities, especially those carried out outside the home so that this age group has a higher risk or tends to experience head trauma more often (R.Gallahera et al., 2020).

This study describes that the majority of respondents were male who experienced head injuries. Meanwhile, some fewer patients were female. Men have a higher prevalence of head trauma due to more risky activities (Global Health Metrics, 2019). This is possible because men often have activities outside the home than women (Kaye, 2015). Two-thirds of head injury cases occur in men more than women (Wolf-Maier et al., 2004). Research in Iran shows that men suffer more injuries than women (Soertidewi, 2012). The injuries that occur are usually the result of traffic accidents, drowning, falls, poisoning. It shows that men have risk factors for trauma than women because men are more physically active than women (Global Health Metrics, 2019).

This study describes the most significant number of respondents, namely the type of work as entrepreneurs. Brain Injury Association of America (2006) reported that in 2007, there were 4 million workers in the United States who suffered non-fatal injuries related to work. Especially jobs that use the most time or provide the most considerable income (Shahlaie, K., Zwienenberg, M., Muizelaar, 2011). Another study states that the highest proportion of head injuries occurs in jobs that require more physical exertion, including self-employed (Guyton, A.C. \& Hall, 2010). According to (Khayat, 2014) the type of work at risk of head injury is self-employed, which is more often outside the home and doing physical activity. Even though the road is not a 
work area, traffic accidents are related to what works if they drive on the highway towards work. In Bangil Hospital, the most patients are self-employed, in the form of factory workers, construction workers, sellers. This type of work is at risk of head injury due to work accidents and is directly related to activities outside the home and workers driving on the road to work or returning from work.

This study describes that most respondents were taken to the emergency room using private vehicles, either using cars or motorbikes. Based on the study results, from 31 samples of severe head injury patients, $51.6 \%$ of the patients received inadequate transportation facilities. The lack of prehospital care services in Indonesia is an obstacle in using adequate means of transportation provided to accident victims (Shahlaie, K., Zwienenberg, M., Muizelaar, 2011). Research conducted by (Bajamal, 2013) revealed that in patients with severe head injuries, $20 \%$ died when the patient arrived at the ER, which means that $20 \%$ of head injury patients were unable to compensate. Several factors influenced secondary complications that continued so that patients experienced biological death when they arrived at the ER. The prehospital stage consisting of first aid, duration of the first treatment, and patient transportation, are factors that contribute to patients' quality of life with severe head injuries (Atiksawedparit et al., 2019). Most of the patients who enter the emergency room use non-ambulance vehicles because of the lack of adequate health transportation facilities. Besides, the lack of knowledge about access to health transportation, namely ambulances, also impacts the minimal use of ambulances by patients. The patient's condition also determines the type of vehicle that takes the patient. A patient with a condition of poor consciousness must get first treatment, so he needs an ambulance (Atiksawedparit et al., 2019). Patients who are taken by ambulance get help in an ambulance by health personnel according to the medical facilities available in the ambulance (Cox, Becker, and Motsumi, 2018). On the other hand, the patient is taken to the emergency room using public or private transportation. The patient does not get help during the trip (Atiksawedparit et al., 2019).

In this study, an assessment of the characteristics of the head injury of the respondents was conducted. Table 2 presents data related to the characteristics 
of the head injury of the respondents. The data show that the majority of respondents experienced minor head injuries. Researchers determined the severity of the patient's head injury using the GCS instrument (Glasgow Coma Scale). The lower the GCS value, the worse the patient's condition, and conversely, the higher the GCS value, the better the head injury patient's condition (Sharf and ElGebali, 2013). The mechanism of injury in head injury patients affects the severity of head injury patients, including traffic accidents, work accidents, falls, and acts of violence (Sasmito, Wihastuti, and Kristianto, 2017). The degree of severity appears to have a strong influence on the chances of survival and healing. In line with research conducted by Suwaryo, (Wihastuti, and Fathoni (2016), patients with dead outcomes were higher in patients with severe GCS, about $60 \%$ compared to mild or moderate GCS namely $22 \%$. More than half of the deaths were found in patients with severe head injuries but not in patients with mild and moderate head injuries (HoonLee et al., 2018). The reduction in GCS in head injury measured objectively is one of the prognostic determinants and emergency indicators. The overall mortality rate for GCS 3-5 is approximately 60\% (HoonLee et al., 2018). It can be concluded that the lower the GCS score, the more predictable the patient is with a poor prognosis

Table 2. Characteristics of Respondents in Head Injury Patients $(n=46)$

\begin{tabular}{llrr}
\hline \multicolumn{1}{c}{ Characteristics of Respondents } & (n) & $(\mathbf{\% )}$ \\
\hline Head Injury Degree & Mild & 31 & 67,4 \\
& Moderate & 12 & 26,1 \\
& Severe & 3 & 6,5 \\
\hline Oxygen Saturation & Normal & 30 & 65,2 \\
Peripheral (SpO2) & Mild Hypoxemia & 12 & 26,1 \\
& Moderate Hypoxemia & 4 & 8,7 \\
\hline Survival Rate (Revised & Good & 32 & 69,6 \\
Trauma Score) & Bad & 10 & 21,7 \\
& Worst & 4 & 8,7
\end{tabular}

This study describes that most respondents have Peripheral Oxygen Saturation (SpO2) in the excellent category. $\mathrm{SpO} 2$ is declared in the excellent category if the test results 
show an oxygen saturation value> $90 \%$ (Hudak, C.M. \& Gallo, 2010). Peripheral oxygen saturation above $90 \%$ has a slight risk of developing hypoxemia, whereas patients with peripheral oxygen saturation below 90\% exhibit a hypoxemic state. Lower oxygen saturation significantly increases the risk of death. Patients with saturation $<80 \%$ have a threefold increase risk-death rate. The patient's peripheral oxygenation status at the time of admission to the ER can affect the prognosis in head injury patients (Filipescu et al., 2020). Adequate oxygenation is maintained in the patient to provide a good prognosis for the patient.

Hypoxic events, especially in the brain, can be avoided to prevent secondary injury to head injury patients (Vacchiano and Silva, 2017). Achieving 100\% optimal oxygen saturation $(\mathrm{SpO} 2)$ due to various factors, including the respondent is still young and the patient's hemodynamic condition is good, vital signs are within normal limits, and hemoglobin is within normal limits oxygen transport can be adequate throughout the body. From the above studies, the oxygen saturation value is related to head injury patients' mortality rate.
This study describes that most respondents have a good categorical survival rate. The survival rate is measured to assess the patient's condition after being given the treatment, whether it gets better or gets worse. The survival rate assessment is carried out immediately after the patient is injured, generally before being admitted to the hospital or in the ER. The Revised Trauma Score (RTS) has been validated as a scoring method to differentiate between patients who have a good or bad prognosis. The RTS assessment can identify more than $97 \%$ of people who will die if they are not treated. The revised trauma score is easy to perform and can predict the prognosis more accurately if used for severe head trauma patients and multiple trauma patients. The ability of RTS to determine life-threatening conditions was $76.9 \%$ (Aspelund et al., 2019). Researchers used RTS with a measuring range of 6 hours after head trauma because it helps determine the mortality rate of head injury and predict the impact of whether it gets worse or gets better, especially in the ER. Researchers categorized the RTS values based on light $=12$, moderate $=11$, heavy $=<10$. The results showed that the RTS score was categorized as light with the highest number of 32 patients $(69.6 \%)$. 
The Somers'd Correlation Test results between the peripheral oxygen saturation value (SpO2) and the survival rate (RTS) obtained $\mathrm{p}=0.00 ; \mathrm{r}=0.846 ; \mathrm{RR}=8.16$. $\mathrm{SpO} 2$ has a strong correlation with patient survival. Patients with good $\mathrm{SpO} 2$ were 8.16 times more likely to survive than patients with bad SpO2. This study describes a significant relationship between peripheral oxygen saturation values and clinical outcome (RTS) in head injury patients in the ER at Bangil Hospital. The statistical data processing results obtained a correlation value of 0.000, which means a significant relationship between peripheral oxygen saturation values and clinical outcomes in head injury patients. The relationship between the two categorical variables is powerful because the correlation value of 0.846 is interval based on the coefficient interval table. The correlation value in the range $0.800-1000$ is categorized as very strong (Purwanto, 2019). Patients with good peripheral oxygen saturation were 8.16 times more likely to survive than patients with poor peripheral oxygen saturation.

In this study, the RTS observation sheet was used with a peripheral oxygen saturation checklist sheet. The RTS is a physiological scoring system with high reliability among raters and demonstrated accuracy in predicting mortality (HoonLee et al., 2018). The RTS assessment is carried out as soon as the patient arrives at the ER. RTS has been validated as a research method to differentiate between good and bad prognoses (Pamungkas, 2014). The instrument used in measuring the peripheral oxygen saturation value is pulse oxymetry. Peripheral oxygen saturation observations are made to prevent and recognize the risk of tissue hypoxia. Tissue hypoxia will cause the risk of secondary trauma to the brain tissue, which will result in the death of the patient (Ostrowski, Pucko, and Matyja, 2020). Peripheral oxygen saturation below 90\% indicates a hypoxemic state. Lower oxygen saturation significantly increased the risk of death. Patients with a saturation $<80 \%$ had a threefold increased risk of mortality (Vacchiano and Silva, 2017).

Hypoxia is a predictor of poor outcome in patients with moderate and severe head injuries due to the patient's additional risk of secondary brain injury; $27-55 \%$ of recorded hypoxia can originate from the scene, in the ambulance/time. transportation, or upon arrival at the ER (Bahloul et al, 2010). Peripheral oxygen 
saturation has a negative correlation with prehospital mortality, which means that the lower the patient's peripheral oxygen saturation, the higher the risk of patient death (Sharf and El-Gebali, 2013). An 8\% decrease will follow every $1 \%$ increase in peripheral oxygen saturation in death risk.

Data from the IMPACT study (International Mission for Prognosis and Clinical Trial) report a strong association between post-injury hypoxia and poor neurological outcome (Shahlaie, K.,
Zwienenberg, M., Muizelaar, 2011). The patient's peripheral oxygenation status at the time of admission to the ER can affect the prognosis in head injury patients. Moreover, maintaining adequate oxygenation can provide a good prognosis for the patient. The same opinion was expressed by (Vacchiano and Silva, 2017), who argued that hypoxemia is associated with reduced outcomes in head injury patients and may increase death risk in patients.

Table 3. Correlation of Peripheral Oxygen Saturation Value with Survival Rate in Head Injury Patients in ER Bangil Hospital ( $\mathrm{n}=46)$

\begin{tabular}{|c|c|c|c|c|c|c|c|}
\hline & & \multicolumn{3}{|c|}{ Oxygen Saturation (SpO2) } & \multirow{2}{*}{ Total } & \multirow{2}{*}{$\mathbf{p}$} & \multirow{2}{*}{$\mathbf{r}$} \\
\hline & & Normal & Mild & Moderate & & & \\
\hline \multirow{4}{*}{$\begin{array}{l}\text { Survival Rate } \\
\text { (RTS) }\end{array}$} & Good & 29 & 3 & 0 & 32 & & \\
\hline & Bad & 1 & 8 & 1 & 10 & 0,000 & 0,846 \\
\hline & Worst & 0 & 1 & 3 & 4 & & \\
\hline & Total & 30 & 12 & 4 & 46 & & \\
\hline
\end{tabular}

Somers'd Test

Research conducted by Ratnasari (2015) stated that brain tissue oxygenation was closely related to several outcome parameters and patient prognosis. The application of interventional therapy to maintain brain tissue oxygenation above a certain threshold can improve mortality and neurological outcomes in brain injury patients (Stillwell, B., 2011). (Vacchiano and Silva, 2017) reported that the mortality rate was higher in patients with low brain tissue oxygenation. Several other studies reported that brain tissue hypoxia below ten $\mathrm{mmHg}$ was associated with poor outcomes after brain injury. The mortality rate was more than $50 \%$ in patients with brain tissue oxygenation of less than 10 $\mathrm{mm} \mathrm{Hg}$ for 30 minutes (Ratnasari, 2015). The investigators concluded that the oxygen saturation value was related to 
head injury patients' clinical outcomes because patients with $100 \%$ oxygen saturation were categorized as good. On the other hand, patients with peripheral oxygen saturation were low or below $90 \%$ at risk of developing hypoxemia and ending with death.

\section{CONCLUSION}

Peripheral oxygen saturation had a significant and strong correlation with patient survival $(\mathrm{p}=0.00 ; \mathrm{r}=0.846 ; \mathrm{RR}=$ 8.16). Patients with good peripheral oxygen saturation were 8.16 times more likely to survive than patients with poor peripheral oxygen saturation. Peripheral oxygen saturation value can be an important indicator in the management of patients with a head injury. The ER is advised to intervene to prevent the patient from falling into a hypoxic state. A good oxygen saturation value can prevent secondary head injury. Low oxygen saturation can be used as an early indicator of tissue hypoxia and is closely related to the patient's mortality rate.

\section{ACKNOWLEDGMENT}

We thank the support in the form of research funds through the 2020 Research Grant scheme managed by LPPM STIKES Widyagama Husada Malang. Thanks to the Education and Training Division of the Bangil Hospital, Pasuruan, for permitting to carry out the research. Our gratitude also does not convey to fellow lecturers, IGD nurses at Bangil Hospital, and students directly involved in technical research.

\section{REFERENCES}

Aspelund, A. L. et al. (2019). Evaluating trauma scoring systems for patients presenting with gunshot injuries to a district-level urban public hospital in Cape Town, South Africa. African Journal of Emergency Medicine. 9(4), 193-196. DOI: 10.1016/j.afjem.2019.07.004.

Atiksawedparit, P. et al. (2019). Prehospital prediction of severe injury in road traffic injuries: A multicenter cross-sectional study. Injury. 50(9), 1499-1506. DOI: 10.1016/j.injury.2019.05.028.

Bahloul et al. (2010). Head Injury. In: Merrits Neurology. Philadelphia: Lippincott William \& Wilkins.

Bajamal, A. H. (2013). Penatalaksanaan Cidera Otak Karena Trauma. Pendidikan Kedokteran Berkelanjutan Ilmu Bedah Saraf.

Cox, M., Becker, T. D. and Motsumi, M. (2018). Head injury burden in a major referral hospital emergency center in Botswana. African Journal of Emergency Medicine. 8(3), 100105. DOI: 10.1016/j.afjem.2018.02.003.

Dixon, J. et al. (2020). Emergency department management of 
traumatic brain injuries: A resource tiered review. African Journal of Emergency Medicine. 10(3), 159166. DOI: 10.1016/j.afjem.2020.05.006.

Filipescu, R. et al. (2020). Improving the Revised Trauma Score's performance using Shock Index, Peripheral Oxygen Saturation, and Temperature-a National Trauma Database study 2011 to 2015, Surgery. Surgery, 167(5), 821-828. DOI:

https://doi.org/10.1016/j.surg.2019.1 2.003 .

G. Lakshmi Prasad, N. Anmol, G. R. M. (2018). Outcome of Traumatic Brain Injury in the Elderly Population: A Tertiary Center Experience in a Developing Country. World Neurosurgery, 111(2), 228-234. DOI:

https://doi.org/10.1016/j.wneu.2017. 12.034 .

Global Health Metrics. (2019). Erratum: Global, regional, and national incidence, prevalence, and years lived with disability for 354 diseases and injuries for 195 countries and territories, 1990-2017: a systematic analysis for the Global Burden of Disease Study 2017 (The Lancet (2018). The Lancet, 393(10190), e44. DOI: 10.1016/S01406736(19)31047-5.

Guyton, A.C. \& Hall, J. (2010). Buku Ajar Fisiologi Kedokteran. Jakarta: EGC.

HoonLee, S. et al. (2018). Predictor of Isolated Trauma in Head: A New Simple Predictor for Survival of Isolated Traumatic Brain Injury. The Journal of Emergency Medicine, 54(4), 427-434.

DOI: https://doi.org/10.1016/j.jemermed.2 018.01.001.

Hudak, C.M. \& Gallo, B. M. (2010). Keperawatan Kritis Pendekatan Holistik. 2nd edn. Jakarta: EGC.

Irmawan, B. (2017). The Influence Of Suction On Changes In The Saturation Oxygen Peripheral On The Patients. Jurnal Ilmiah Sehat Bebaya, 1(1).

Kaye, A. (2015). Essential Neurosurgery. 3rd edn. USA: Blackwell Publishing.

Khayat, N. (2014). Correlation of revised trauma score with mortality rate of traumatic patients within the first 24 hours of Hospitalization. ZJRMS, 16(11), 33-36.

Marya, J. et al. (2017). Impact of compulsory helmet legislation on mortality rate and types of head and facial injuries in Jabalpur. Journal of Oral and Maxillofacial Surgery, Medicine, and Pathology, 29(1), 2428.

DOI: https://doi.org/10.1016/j.ajoms.2016. 08.008 .

Ostrowski, R. P., Pucko, E. and Matyja, E. (2020). The effectiveness of hyperbaric oxygen modalities against a vascular component of traumatic brain injury. Brain Hemorrhages, 1(2), 118-123. DOI: 10.1016/j.hest.2020.04.002.

Pamungkas (2014). Hubungan Antara RTS Dengan Angka Mortiliti Pasien Cedera Kepala RSUD Dr Moewardi. Surakarta. Surakarta: Stikes Kusuma Husada Surakarta.

Papadimitriou-Olivgeris, M. et al. (2020). Predictors of mortality of trauma

DOI: 10.32668/jitek. v8i2.512 
patients admitted to the ICU: a retrospective observational study', Brazilian Journal of Anesthesiology (English Edition), (xxxx), 1-8. DOI: 10.1016/j.bjane.2020.12.006.

Purwanto (2019). Analisis Korelasi dan Regresi linier dengan SPSS 21 (Panduan Praktis untuk Penelitian Ekonomi Syariah). Magelang: StaiaPress.

R.Gallahera, J. et al. (2020). Trends in head injury associated mortality in Malawi, Injury. DOI: https://doi.org/10.1016/j.injury.2020. 12.031 .

Ratnasari (2015). Hubungan Penanganan Oksigenasi Pasien Gawat Dengan Peningkatan Kesadaran Kuantitatif Pada Pasien Cedera Otak Sedang Di IGD RSUD DR Abdoer Rahem Situbondo, Jurnal Keperawatan Fikes UMJ.

Riskesdas, K. (2018). Hasil Utama Riset Kesehatan Dasar (RISKESDAS)', Journal of Physics A: Mathematical and Theoretical, 44(8), 1-200. DOI: 10.1088/1751-8113/44/8/085201.

Sasmito, N. B., Wihastuti, T. A. and Kristianto, H. (2017). Analisis Faktor yang Berhubungan Dengan Outcome Pasien Cedera Kepala Yang Dirujuk di IGD RSUD dr. Iskak Tulungagung Melalui Pendekatan Model Interpersonal Nursing Hekdegrad E. Peplau, Jurnal Kesehatan Mesencephalon, 3(2), 91-104. DOI: 10.36053/mesencephalon.v3i2.41.

Shahlaie, K., Zwienenberg, M., Muizelaar, P. (2011). Management of Traumatic Brain Injury In: Youmans Neurological Surgery. Philadelphia:
WB Saunder Company.

Sharf, M. S., and El-Gebali, M. A. (2013). Correlation between Glasgow coma scale and Jugular venous oxygen saturation in severe traumatic brain injury, Egyptian Journal of Anaesthesia, 29(3), pp. 267-272. DOI: 10.1016/j.egja.2013.02.008.

Soertidewi, L. (2012). Penatalaksanaan Kedaruratan Cedera Kranioserebral. CDK-193, 39 (5), 327-331

Stillwell, B., S. (2011). Pedoman Keperawatan Kritis. Edited by 3 . Jakarta: EGC.

Sumarno, M. H. (2016). Glasgow Coma Scale (Gcs), Tekanan Darah Dan Kadar Hemoglobin Sebagai Prediktor Kematian pada Pasien Cedera Kepala. Jurnal Ilmiah Kesehatan Keperawatan, 12(3).

Suwaryo, P. A. W., Wihastuti, T. A. and Fathoni, M. (2016). Analisis Faktorfaktor yang berhubungan dengan Outcome Pasien Cedera Kepala di IGD RSUD Prof Dr. Margono Soekardjo Purwokerto. Jurnal Ilmiah Kesehatan Keperawatan, 12(3), 154-164.

Vacchiano, C. and Silva, S. (2017) Characterization of bilateral frontal lobe cerebral oxygen saturation in patients with mild traumatic brain injury. Nursing Outlook, 65(5), S36S43.

DOI: https://doi.org/10.1016/j.outlook.201 7.07.013.

Wijaya, P. (2013). Keperawatan Medikal Bedah (keperawatan dewasa). Yogyakarta: Nuha Medika.

Wolf-Maier,K. et al. (2004). Hypertension 
129 Jurnal Ilmu dan Teknologi Kesehatan, Vol. 8, Nomor 2, March 2021, hlm:115-129

Treatment and Control in Five European Countries, Canada, and the United States. Hypertension, 10-17.
DOI:

10.1161/01.HYP.0000103630.72812 .10 .

DOI: $10.32668 /$ jitek. v8i2.512 